\title{
Heavy metals in Bushmeat from New-Bussa and its environs, Nigeria
}

\section{*1 ADELAKUN, KM; ${ }^{2}$ KEHINDE, AS; ${ }^{1} \mathrm{JOSHUA,} \mathrm{DA;}{ }^{1}$ IBRAHIM, AO; ${ }^{1}$ AKINADE, TG}

\author{
${ }^{*}$ Federal College of Wildlife Management of Forestry Research Institute of Nigeria, P.M.B.268, New Bussa, Nigeria \\ ${ }^{2}$ Forestry Research Institutes of Nigeria, P.M.B. 5054, Ibadan, Nigeria \\ *Correspondance email: adelakunkehinde@gmail.com, Tel.: +234803478 4947
}

\begin{abstract}
Bushmeat have provided complimentary protein for human population across the world over the centuries. This study assessed the concentration of heavy metals in bushmeats in New Bussa and its environs. Three carcass of bush meat (Kobus kob (Kob), Tragelaphus scriptus (Bushbuck) and Sylvicapra grimmia (Duiker)) were sourced from the study area. The carcass was digested and concentrations of nine heavy metals $(\mathrm{Mn}, \mathrm{Fe}, \mathrm{Cu}, \mathrm{Zn}, \mathrm{Pb}$, $\mathrm{Cr}, \mathrm{Ni}, \mathrm{Co}$ and $\mathrm{Cd}$ ) were determined using Atomic Absorption Spectrophotometer (AAS). Results obtained for the heavy metal analysis were subjected to one-way analysis of variance (ANOVA) while Pearson's correlation was used to determine the relationship in the samples. The heavy metal concentration in muscle tissues of the selected bushmeat revealed that zinc with $815.00 \pm 13.00 \mathrm{mg} / \mathrm{kg}$ in Kob was the highest mean value of all meat samples, followed by Iron $(479.00 \pm 10.00 \mathrm{mg} / \mathrm{kg}$ ) in Duiker while $\mathrm{Pb}$ level in Bushbuck $213.00 \pm 3.00 \mathrm{mg} / \mathrm{kg}$ is outrageously the highest. Copper, Chromium and Nickel did not exceed the permissible limits as set by FEPA/WHO. The concentration pattern of heavy metals in bush meat show that Sylvicapra grimmia and Tragelaphus scriptus had the same pattern of $\mathrm{Zn}>\mathrm{Fe}>\mathrm{Pb}>\mathrm{Cr}>\mathrm{Mn}>\mathrm{Cu}>\mathrm{Co}>\mathrm{Ni}>\mathrm{Cd}$ concentration while Kobus kob pattern of association is $\mathrm{Zn}>\mathrm{Fe}>\mathrm{Cr}>\mathrm{Pb}>\mathrm{Ni}>\mathrm{Cu}>\mathrm{Co}>\mathrm{Cd}>\mathrm{Mn}$. The comparative study of the heavy metal concentrations revealed that Zinc $(\mathrm{Zn})$ recorded the highest frequency, followed by Iron $(\mathrm{Fe})$ and Lead $(\mathrm{Pb})$. This study has shown that high level of $\mathrm{Pb}$ in the samples from the study area is a matter of concern in bush meat consumption in the study area; hence people should be warned of impending danger in the consumption of heavy metals contaminated bush meat.
\end{abstract}

DOI: $\underline{\text { https://dx.doi.org/10.4314/jasem.v24i4.19 }}$

Copyright: Copyright $(C 2020$ Adelakun et al. This is an open access article distributed under the Creative Commons Attribution License (CCL), which permits unrestricted use, distribution, and reproduction in any medium, provided the original work is properly cited.

Dates: Received: 11 February 2020; Revised: 14 March 2020; Accepted: 22 March 2020

Keywords: Bushmeat, heavy metals, concentration, toxicity, contaminated

Globally, game animals also known as bush (wild) meat have a potential for meat production and serve as a good source of protein to rural poor in Africa (Fonweban and Njwe, 1990). The commercial benefits and valuable nutritional source derived from bush meat consumption plays direct role in the livelihoods of nearly 150 million people in the world (Hunt et al., 2009).The demand for bush meat has been met through hunting from the wild by the use of guns, cutlasses, chase dogs, baiting with chemicals, and bush burning (Oduro and Kankam, 2000). Hunting practices such as use of guns and baits used for killing wild animals could be a great threat to human life due to the presence of harmful chemicals or heavy metals such as Lead $(\mathrm{Pb})$, Cadmium (Cd), Manganese (Mn), Iron $(\mathrm{Fe})$, Zinc $(\mathrm{Zn})$ and Copper $(\mathrm{Cu})$, etc. (Hunt et al., 2009). Heavy metals are dangerous elements of the earth crusts as they tend to bioaccumulate by increasing in concentration level in biological organism over the time (Dural et al., 2007). Toxic substances in meat tissues can be caused by a variety of sources including animal drugs, pesticides, feed and other agricultural or industrial chemicals substances
(Khalafalla et al., 2011). Instances of heavy metal contamination in meat products during processing have also been reported by various authors (Akan et al., 2010; Harlia and Balia, 2010). Methods such as burning off the hairs of the animals in flame fuelled by various substances such as wood mixed with spent engine oil, plastics mixed with refuse or tyres. These materials contain toxic substances such as heavy metals which can contaminate the meat and render them unfit for human consumption (Okiei et al., 2009). In other cases, contaminated animal feed and rearing of livestock in proximity to polluted environment were reportedly responsible for heavy metal contamination in meat (Khalafalla et al., 2011). Heavy metals in their standard state have a specific gravity (density) of more than about $5 \mathrm{~g} / \mathrm{cm} 3$. Some of them, such as copper, nickel, chromium and iron, are essential in very low concentrations for the survival of all forms of life, Specific elements that are normally toxic for some organisms are under certain conditions, beneficial, and examples include vanadium, tungsten, and cadmium. Only when they are present in greater quantities, can these, cause metabolic anomalies. The toxicity of 
heavy metals is one of the major environmental problems and its danger to animal and human health is as a result of bioaccumulation of these metals through food chain (Aschner, 2002) and the resultant effect on brain cells calls for concern. Therefore, heavy metals bio-accumulated, bio- absorbed, bio-magnified through the food chain and finally assimilated by human can result to health risks (Agah et al., 2009). These pollutants often have direct physiological toxic effects because they are stored or incorporated in tissues, sometimes permanently (Abd El-Salam et al., 2013). Heavy metals such as mercury, plutonium, and lead are toxic metals that have no known vital or beneficial effect on organism and their accumulation over time in the bodies of animals and humans can cause serious ailments. Among all heavy metals, however, cadmium and lead are known as highly toxic (Binkowski, 2012). The risk associated with the exposure to heavy metals present in food product has aroused widespread concern in human health. Cadmium is primarily toxic to kidney, especially to proximal tubular cells. Bone demineralization is affected by cadmium toxicity directly by bone damage and indirectly as results of renal dysfunction (Solidum et al., 2013).

Information on the ensuing heavy metals concentrations in consumed bush meat is quite important. This interest was to ensure safe consumption of bush meat and minimizing the potential hazard effects of these metals on human health which this work will validate. The need for a better understanding of heavy metal composition in this animal is essential if human communities are to be safe from the metals adverse effects. Also, the study will provides baseline information on the abundance of some heavy metals contents on bush meat in our rural communities.

\section{MATERIALS AND METHOD}

Study location: New Bussa is headquarter of Borgu Local Government Area of Niger state, Nigeria. It is located on latitude $9^{0} 53^{\prime} \mathrm{N}$ and longitude $4^{0} 31^{\prime} \mathrm{E}$, covering a land mass of about $16,200 \mathrm{~km}^{2}$. It has a population of about one hundred and two thousand three hundred and seventy $(102,370)$ people as revealed by 1996 census (Ross, 2010).

Meat sample collection: Meat samples of smoked Kobus kob (Kob), Sylvicapra grimmia (Duiker) and Tragelaphus scriptus (Bush buck) were collected from the study areas. The samples muscles are filleted into sterile plastic bags and transported to the University of Ibadan Central Laboratory for analysis. Samples will be digested according to Akan et al. (2012).

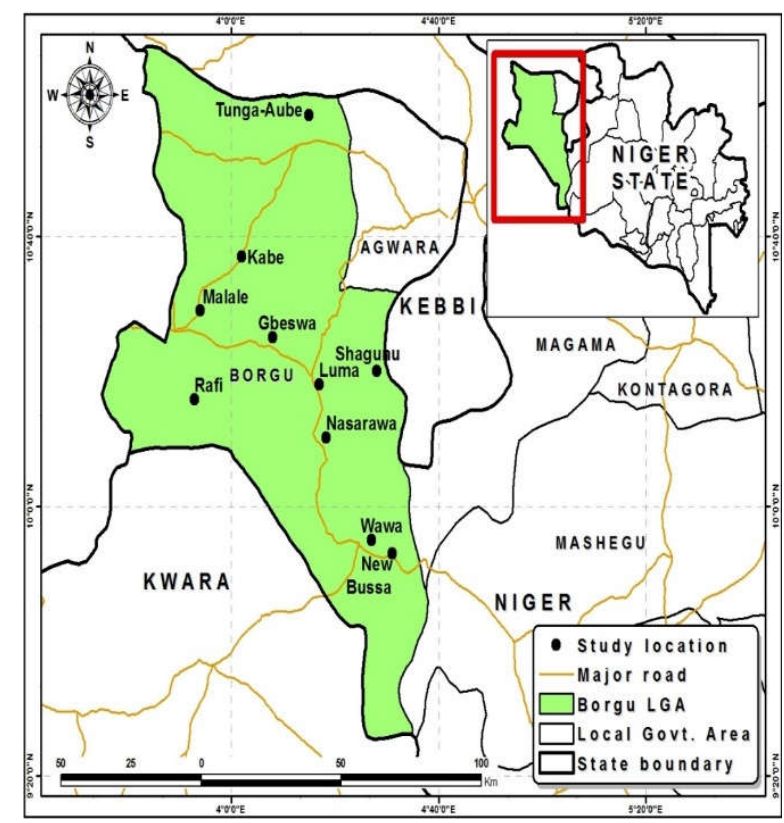

Fig 1: Map of Borgu Local Government showing New Bussa and its environs (Ross, 2010)

Determination of , Fe, $\mathrm{Cu}, \mathrm{Zn}, \mathrm{Pb}, \mathrm{Cr}, \mathrm{Ni}, \mathrm{Co}$ and $\mathrm{Cd}$ will be read directly on each final solution using Perkin-Elmer AAnalyst 300 Atomic Absorption Spectroscopy (AAS).

Data analysis: Results obtained for the heavy metal analysis were subjected to one-way analysis of variance (ANOVA) to find out the significant differences in heavy metals concentration of the bush meat using Statistical Package for Social Sciences (SPSS). Pearson correlation was used to determine the variation the relationship in the study.

\section{RESULTS AND DISCUSSION}

Heavy metal concentrations in muscles of Bush meat from New Bussa and its environs: The heavy metal concentration in muscle tissue of the selected bush meat is shown in Table 4.1, in which zinc recorded the highest mean value in all the samples, followed by Iron and Cadmium which is the least. Copper, Chromium and Nickel did not exceed the permissible limits as set by FEPA/WHO. Metals concentration were significantly differ $(p>0.05)$ in various samples except for Copper which was also detected below maximum permissible limit.

Manganese and Cadmium concentration in Sylvicapra grimmia and Tragelaphu sscriptus show no significant variation while Zinc concentration in Kobus kob and Tragelaphus scriptus also not significantly varied. Presence of these metal elements had earlier being reported by Ampofo et al. (2017) in bush meat including antelopes from Kumasi, Ghana. Significant 
high level of $\mathrm{Zn}$ and $\mathrm{Fe}$ recorded in the study substantiate the result documented by Oladunjoye et al. (2015) for ungulates in Ago-Iwoye, Ogun State, Nigeria.

From the results presented in the table1 below there was clear trend in the distribution of heavy metals in the entrails of the studies bush meats. All the heavy metals selected for the study are presented in the samples. The highest concentration of Zinc, was found in the meat of Kobus kob while the lowest in the meat of the Sylvicapra grimmia. Zinc is an essential cofactor element for several enzymatic reactions in human body and therefore needed in the human diet (Linnik and Zubenko, 2000) hence its deficiency as well as excesses can be harmful (Orebiyi et al., 1010). Recent research has shown that zinc is extremely important especially in foetal development and the nutrition of infants. The adult human body contains about $2.3 \mathrm{~g}$ of zinc which occurs mostly in over 100 enzymes. The normal daily requirement for zinc is 15 $\mathrm{mg}$ for adult and $5 \mathrm{mg}$ for children. Zinc plays a role in carbohydrate, lipid and protein metabolism and in the synthesis and breakdown of DNA. Because of these functions, zinc deficiency in the foetal will result in retarded growth malformation of body, and chromosomal abnormalities. A zinc deficiency after birth may result in dwarfism, poor appetite, mental lethargy, etc. Excess amount of zinc on the other hand can cause stomach cramps, nausea, vomiting, central nervous system disorder (Nriagu, 1980). Most of the rocks in the earth's crust contain zinc in varying concentrations.

Iron was found to be high in the meat of Sylvicapra grimmia and low in the meat of Kobus kob, Iron is regarded as one of the essential elements for humans. Approximately 3000 to $5000 \mathrm{mg}$ of iron exists in the human body (Landis and $\mathrm{Yu}, 1995$ ). Therefore, as long as the quantity of iron in the environment is not too large, it may not be harmful to the human body.

Majority of the heavy metals study exceeds the permissible limit; the amount of $\mathrm{Cu}$ observed in the various meat samples fell within the range of $7.00 \pm 0.52$ to $7.60 \pm 0.20$. The highest copper, $\mathrm{Cu}$ concentration was observed in the meat of the Bushbuck. Some forms of human activity such as the application of agricultural fertilizers and industrial waste water disposal, release copper directly into the soil. Copper released into the environment eventually end up in soils or surface waters (Solidum et al. 2013). Bushbuck is herbivorous animals; feeding on roots, tubers, grass, grains of cereals and wood of all sorts. During digging for tubers, and roots, they might consume bits of soil on roots and tubers (Golow 1993), thereby introducing copper through their mode of feeding. The lowest concentration of copper was in the meat of Kob.

Cadmium $(\mathrm{Cd})$ and Lead $(\mathrm{Pb})$ are cumulative poisons and could be exceptionally toxic (Orebiyi et al., 2010; Dural et al., 2007) and its likely to bioaccumulation in biological organisms is inevitable (Dural et al., 2007). $\mathrm{Cd}$ exists in low concentrations in all samples except in Kob where it is significantly higher. The highest level of Cd detected in the Kobs could therefore be as a result of having more contact with both soil and plants as compared to the other animals. $\mathrm{Cd}$ is primarily toxic to kidney, especially to proximal tubular cells. Bone demineralization is affected by cadmium toxicity directly by bone damage and indirectly as a result of renal dysfunction (Solidum et al. 2013). Cd may catalyze diabetes-induced effects on kidneys. Kidney damage may further progress to end stage renal disease (ESRD) and death if exposure is high and prolonged. Recent investigations show that Cd may also play a role in the development of other cancers, such as testicular cancer, bladder cancer, pancreatic cancer and cancer of the gall bladder (Ilie et al. 2007). On the other hand, $\mathrm{Pb}$ is a toxic metal that has no known vital or beneficial effect on organisms and its accumulation over time in the bodies of animals and humans can cause serious ailments (Binkowski, 2012). The highest concentration of $\mathrm{Pb}$ was $213.00 \pm 3.00$ and the lowest at $12.15 \pm 0.11$, all above the tolerable limit of $2 \mathrm{mg} / \mathrm{kg}$. Its highest concentration was recorded in the meat of Bushbuck and the lowest in that of the Kob and this may pose serious health challenges to consumers because of its non-degradable nature (Agah et al., 2009). $\mathrm{Pb}$ may enter the atmosphere during mining, smelting, refining, manufacturing processes and by the use of lead containing products. The sources of $\mathrm{Pb}$ contamination usually come from the air, water they drink and food animals eat (Abd El-Salam et al., 2013). However, all the meat samples analysed in the study contain $(\mathrm{Pb})$ in high quantities (above the tolerable limit), and this could be attributed to the use of gun for hunting of bush meat as bullet shot contain dispersion of heavy metals including $\mathrm{Pb}$ fragment (Ampofo et al., 2017). Accumulation patterns of heavy metals in Bush meat in the study area: Table 2 presents the concentration pattern of heavy metals in bush meat in the study area, in which Sylvicapra grimmia and Tragelaphus scriptus have the same pattern of accumulation $\mathrm{Zn}>\mathrm{Fe}>\mathrm{Pb}>\mathrm{Cr}>\mathrm{Mn}>\mathrm{Cu}>\mathrm{Co}>\mathrm{Ni}>\mathrm{Cd}$ while Kobus kob is slightly varies in its accumulation pattern $(\mathrm{Zn}>\mathrm{Fe}>\mathrm{Cr}>\mathrm{Pb}>\mathrm{Ni}>\mathrm{Cu}>\mathrm{Co}>\mathrm{Cd}>\mathrm{Mn})$. These patterns of accumulation are similar to observation described for ungulates by Oladunjoye et al. (2015). 
Table 1: Heavy metal concentrations in muscles of Bush meat from New Bussa and its environs

\begin{tabular}{|c|c|c|c|c|}
\hline & $\begin{array}{l}\text { Kobus kob } \\
\text { (Kob) }\end{array}$ & $\begin{array}{l}\text { Sylvicapra } \\
\text { grimmia } \\
\text { (Duiker) }\end{array}$ & $\begin{array}{l}\text { Tragelaphus } \\
\text { scriptus } \\
\text { (Bushbuck) }\end{array}$ & $\begin{array}{l}\text { FEPA/WHO maximum } \\
\text { permissible limits } \\
(2003 / 2008)\end{array}$ \\
\hline \multicolumn{5}{|l|}{ Heavy metals (mg/kg dry t) } \\
\hline Manganese (Mn) & $2.52 \pm 0.04^{\mathrm{a}}$ & $9.55 \pm 0.05^{\mathrm{b}}$ & $10.00 \pm 0.55^{\mathrm{b}}$ & 1 \\
\hline Iron $(\mathrm{Fe})$ & $226.00 \pm 13.61^{\mathrm{a}}$ & $479.00 \pm 10.00^{\mathrm{c}}$ & $373.00 \pm 3.00^{\mathrm{b}}$ & 100 \\
\hline Copper $(\mathrm{Cu})$ & $7.00 \pm 0.52^{\mathrm{a}}$ & $7.55 \pm 0.05^{\mathrm{a}}$ & $7.60 \pm 0.20^{\mathrm{a}}$ & 30 \\
\hline Zinc $(\mathrm{Zn})$ & $815.00 \pm 13.00^{b}$ & $765.00 \pm 21.00^{\mathrm{a}}$ & $802.00 \pm 2.00^{\mathrm{b}}$ & 100 \\
\hline Lead $(\mathrm{Pb})$ & $12.15 \pm 0.11^{\mathrm{a}}$ & $22.00 \pm 1.45^{\mathrm{b}}$ & $213.00 \pm 3.00^{\mathrm{c}}$ & 2 \\
\hline Chromium (Cr) & $13.55 \pm 0.10^{\mathrm{c}}$ & $9.70 \pm 0.20^{\mathrm{a}}$ & $12.55 \pm 0.20^{\mathrm{b}}$ & 50 \\
\hline Nickel (Ni) & $9.35 \pm 0.05^{\mathrm{c}}$ & $5.30 \pm 0.15^{\mathrm{b}}$ & $2.35 \pm 0.03^{\mathrm{a}}$ & 10 \\
\hline Cobalt (Co) & $6.20 \pm 0.10^{c}$ & $5.50 \pm 0.38^{\mathrm{b}}$ & $4.00 \pm 0.42^{\mathrm{a}}$ & - \\
\hline Cadmium (Cd) & $5.35 \pm 0.20^{\mathrm{b}}$ & $0.54 \pm 0.03^{\mathrm{a}}$ & $0.73 \pm 0.02^{\mathrm{a}}$ & $<1$ \\
\hline
\end{tabular}

Table 2: Accumulation patterns of heavy metals in Bush meat in the study area

\begin{tabular}{|c|c|}
\hline Animal species & Pattern of the association of heavy metal concentrations \\
\hline Kobus kob (Kob) & $\mathrm{Zn}>\mathrm{Fe}>\mathrm{Cr}>\mathrm{Pb}>\mathrm{Ni}>\mathrm{Cu}>\mathrm{Co}>\mathrm{Cd}>\mathrm{Mn}$ \\
\hline Sylvicapr agrimmia (Duiker) & $\mathrm{Zn}>\mathrm{Fe}>\mathrm{Pb}>\mathrm{Cr}>\mathrm{Mn}>\mathrm{Cu}>\mathrm{Co}>\mathrm{Ni}>\mathrm{Cd}$ \\
\hline Tragelaphus scriptus (Bushbuck) & $\mathrm{Zn}>\mathrm{Fe}>\mathrm{Pb}>\mathrm{Cr}>\mathrm{Mn}>\mathrm{Cu}>\mathrm{Co}>\mathrm{Ni}>\mathrm{Cd}$ \\
\hline
\end{tabular}

Table 3. Correlation of different heavy metals accumulated within the samples

\begin{tabular}{llllllllll}
\hline Heavy metals & $\mathbf{M n}$ & $\mathbf{F e}$ & $\mathbf{C u}$ & $\mathbf{Z n}$ & $\mathbf{P b}$ & $\mathbf{C r}$ & $\mathbf{N i}$ & $\mathbf{C o}$ & $\mathbf{C d}$ \\
\hline Manganese (Mn) & 1 & & & & & & & & \\
Iron (Fe) & $0.88^{* *}$ & 1 & & & & & & \\
Copper (Cu) & $0.74^{*}$ & 0.61 & 1 & & & & & \\
Zinc (Zn) & -0.58 & $-0.81^{* *}$ & -0.22 & 1 & & & & \\
Lead (Pb) & 0.58 & 0.13 & 0.43 & 0.20 & 1 & & & \\
Chromium (Cr) & -0.65 & $-0.93^{* *}$ & -0.46 & $0.86^{* *}$ & 0.22 & 1 & & \\
Nickel (Ni) & $-0.93^{* *}$ & -0.64 & -0.68 & 0.29 & $-0.84 * *$ & 0.337 & 1 & & \\
Cobalt (Co) & $-0.73^{*}$ & -0.371 & -0.45 & -0.12 & $-0.93^{* *}$ & 0.05 & $0.91 *$ & 1 & \\
Cadmium (Cd) & $-0.99^{* *}$ & -0.91 & -0.73 & 0.63 & -0.51 & $0.72 *$ & $0.89 *$ & $0.69 *$ & 1
\end{tabular}

**Correlation is significant at the 0.01 level (2-tailed). ${ }^{*}$ Correlation is significant at the 0.05 level (2-tailed). Source: Laboratory Analysis,

Correlation of different heavy metals accumulated within the samples: The Pearson's correlation coefficient in table 3 show the relationship among the heavy metals concentration in all samples. Manganese is directly correlated to $\mathrm{Fe}$ and $\mathrm{Cu}$ significantly ( $p>0.01$ and $p>0.05$ respectively) though show inverse relationship with $\mathrm{Ni}$ and $\mathrm{Co}(\mathrm{p}>0.05)$.Fe show strong and significant negative relationship with $\mathrm{Zn}$ and $\mathrm{Cr}$ ( $>0.01)$ which implies that increase in Fe will result to decrease in $\mathrm{Zn}$ and $\mathrm{Cr}$. $\mathrm{Cd}$ is directly proportional and significant to $\mathrm{Cr}, \mathrm{Co}(\mathrm{p}>0.05)$ and $\mathrm{Ni}(\mathrm{p}>0.01)$ while the relationship with $\mathrm{Mn}$ is inverse and significant $(p>0.01)$ hence, increase in $\mathrm{Cd}$ will increases the concentration of $\mathrm{Cr}$, Co and $\mathrm{Ni}$ but will lead to decrease in concentration of $\mathrm{Mn}$. Increase in $\mathrm{Co}$ will significantly $(\mathrm{p}>0.05)$ increases the concentration of $\mathrm{Ni}$ but $\mathrm{Pb}$ will significantly $(\mathrm{p}>0.01)$ decreases. $\mathrm{Cr}$ and $\mathrm{Zn}$ are also significant and have direct relationship.

Conclusion: This study revealed that consuming bush meat from New Bussa and its environs may not be harmful to consumers because observed values of major heavy metals (non-essential) were below the permissible limits issued by $\mathrm{FAO} / \mathrm{WHO}$ for human consumption. However, $\mathrm{Pb}$ is higher than permissible level so, it is a matter of concern in bush meat consumption in the study area.

\section{REFERENCES}

AbdE-Salam, NM; Ahmad, S; Asia, B; Rais, AK; Bibi, A; Ullah, R; Shad, AA; Muhammad, Z; Hussain, I (2013). Distribution of Heavy Metals in the Liver, Kidney, Heart, Pancreas and Meat of Cow, buffalo, Goat, Sheep and Chicken from Kohat market Pakistan, Life Sci. Jour. 10 (7s): 937-940

Agah, AL; Mepba, HD; Ekpo, MB (2009). Heavy metal contaminants and processing effects on the composition, storage stability and fatty acid profiles of five common commercially available fish species in Oron Local Government, Nigeria. Food Chem. 97:490-497.

Akan, JC; Abdulrahman, FI; Sodipo, OA; Chiroma, YA (2010). Distribution of Heavy Metals in the Liver, Kidney and Meat of Beef, Mutton, Caprine and Chicken from KasuwanShanu Market in Maiduguri Metropolis, Borno State, Research Journal of Applied Sciences, Engineering and Technol. 2(8): $743-748$ 
Akan, JC; Salwa, M; Yikala, BS; Chellube, ZM (2012). Study on the Distribution of Heavy Metals in Different Tissues of Fishes from River Benue in Vinkalang, Adamawa state, Nigeria. British Journal of Applied Science and Technol. 2 (4): 311 -333.

Ampofo, HJ; Emikpe, BO; Asenso, TN; Asare, DA; Yeboah, R; Jarikre, TA; Jagun-Jubril, A (2017). Hunting practices and heavy metals concentrations in fresh and smked wildmeats in Kumasi, Ghana. $J$. Res. Forestry, Wild. Environ. 9(3):43-49.

Aschner, M (2002). Neurotoxic mechanism of fishbonemethylmetry. Environ. Toxicol. Phamacol. 12:101-102.

Binkowski, MN (2012). Preliminary results of cadmium and lead concentration in pectoral muscles of mallards and coots shot in 2006 in southern Poland, J. Microbiol. Biotech. Food Sci. 1: 120-1128.

Dural, DA; Bakare, OK; Ayodele, IA (2007). Trade in the wild mammalian Species for Traditional medicine in Ogun State, Nigeria Global J. Med. Res. 12 (3): 6-21.

Fonweban, JN; Njwe, RM (1990). Feed Utilization and life weight gain by African giant rat (Crisitomys gambianus, Water House) at Dschana in Cameroon, Tropicult., 8:118-120.

Food and Agriculture Organization of the United Nations (FAO) (2003). Chronic Under nutrition among Children: An Indicator of Poverty. FAO/SDRN \& ESNA, Rome.

Harlia, E; Balia, RL (2010). The Food Safety of Livestock Products (Meatball, Corned Beef, Beef Burger and Sausage) Studied from Heavy Metal Residues Contamination, Animal Product. 12 (1):50-54.

Hunt, WG; Watson, RT; Oaks, LJ; Parish, CN; Burnham, KK; Tucker, RL; Belthoff, JR; Hart, G (2009). Lead Bullet Fragments in Venison from Rifle-Killed Deer: Potential for Human Dietary Exposure. PLoS ONE 4 (4): e5330.

Khalafalla, FA; Ali, FH; Schwagele, F; Abd-El- Wahab, MA (2011). Heavy metal residues in beef carcasses in Beni-Seuf abattoir, Egypt, Veterinaria Italiana, 47(3): 351-361.

Landis, WG; Yu, M (1995). Introduction to environmental toxicology: impacts of chemicals upon ecological systems. 2nd edition, Boca Raton (Fla.): Lewis. 390p. available at: https://lib.ugent.be/catalog/rug01:000463154
Linnik, PM; Zubenko, IB (2000). Role of bottom sediments in the secondary pollution of aquatic environments by Heavy-metal compounds. Lakes and Reservoirs: Res. and Man. 5: 11-21.

Nriagu, JO (1980) Production Uses, and Properties of Cadmium. John Wiley \& Sons, New York.

Oduro, W. and Kankam, B. (2002). Environmental and public health hazards of traditional grasscutter (ThryonomysSwinderianus) hunting. In: (K.A. Weidinger (Eds) proceedings of a workshop on promoting Grasscutter production for poverty reduction in Ghana, Pp 19-22.

Okiei, W; Ogunlesi, M; Alabi, F; Osiughwu, B; Sojinrin, M (2009). Determination of toxic metal concentrations in flame -treated meat products, ponmo, African Journal of Biochemistry Research. 3(10): 332- 339.

Oladunjoye, RY; Asiru, RA; Shokoya, DA (2015). Heavy metals $(\mathrm{Cd}, \mathrm{Pb}, \mathrm{Cu}, \mathrm{Fe}, \mathrm{Cr}, \mathrm{Mn}, \mathrm{Zn})$ contents in ungulates of Ogun State Agricultural Farm Settlement, Ago-Iwoye, Nigeria. J. Biol. Life Sci. 6(2): 119-129.

Orebiyi, EO; Awomeso, JA; Idowu, OA; Martins, O; Taiwo, AM (2010). Assessment of Pollution Hazards of Shallow well in Abeokuta and Environs South West, Nigeria. American J. Environ. Sci. 6(1): 50-56.

Ross, C (2010). Conditionality and logging reform in the tropics. In: Institutions for Environmental Aid: Problems and Prospects, eds. Keohane, R. O. and Leve, M A. Pp 167-197. MIT Press, Cambridge Massachusetts.

Solidum, MD; Ar-Raquib, DC; Abdulla, JH; Evangelista, V (2013). Quantitative Analysis of Lead, Cadmium and Chromium found in Selected Fish marketed in Metro Manila, Philippines, International Journal of Environmental Science and Development; 4( 2).

USDA, (2006). Foreign Agricultural Services GAIN Report; Global GAIN Report No. CH6064, Chinese People"s Republic of FAIRS products. Specific maximum levels of contaminants in foods, Jim Butterworth and Wu Bugang. Pp. 1-60.

World Health Organisation, WHO (2008). Guidelines for Drinking Water Quality. 3rd Edn. Health Criteria and Supporting Information. WHO, Geneva, pp: 668. Retrieved from: http://www.who.int/water _sanitation_health/dwq/fulltext.pdf. 